\title{
ОСОБЛИВОСТІ РОСТУ ЧИСТОПОРОДНИХ І ПОМІСНИХ СВИНЕЙ З РІЗНОЮ ІНТЕНСИВНІСТЮ ФОРМУВАННЯ
}

\section{О. В. ВОЛОЩУК}

Інститут свинарства і агропромислового виробництва НААН (Полтава, Україна) 0970293469@ukr.net

Наведено результати досліджень з вивчення особливостей росту чистопородних $i$ помісних свиней за індексами інтенсивності формування, рівномірності та напруги росту. Вивчена залежність між середньодобовими приростами у вікові періоди 0-3; 1-3 і 4-6 місяиів з жсивою масою у 6 місяиів ( $r=0,676 ; 0,667$ i 0,845). Статистично значуща кореляція між середньодобовими приростами та індексами росту, визначеними в початковий період онтогенезу ( $r=0,558-0,950)$, свідчить про доцільність використання ичих показників при відборі свиней. Одержані дані доводять можливість раннього прогнозування продуктивності свиней, щзо сприятиме підвищенню ефективності товарного свинарства.

Ключові слова: індекси росту, інтенсивність формування, рівномірність росту, напруга росту, онтогенез, чистопородний молодняк

\section{GROWTH PECULIARITIES OF PUREBREED AND CROSSBREED PIGS WITH DIFFER- ENT INTENSITY OF FORMATION}

\section{A. V. Voloshchuk}

Institute for pig breeding and agricultural production NAAS (Poltava, Ukraine)

The results of researches on the peculiarities of growth of purebred and crossbreed swine according to the indices of the intensity of formation, uniformity and growth voltage are given. The dependencies between average daily increments in age groups $0-3 ; 1-3$ and 4-6 months with a live weight of 6 months ( $r=0.676,0.667$ and 0.845$)$ were established. The statistically significant correlation between average daily increments and growth indices, determined in the initial period of ontogenesis ( $r=0.558-0.950)$, testifies to the expediency of using these indicators in the selection of pigs. The obtained results testify to the possibility of early prediction of pig production during the initial period of ontogenesis, which will increase the efficiency of pig breeding.

Keywords: growth indices, formation intensity, uniformity, growth intensity, ontogenesis, purebreed young

\section{ОСОБЕННОСТИ РОСТА ЧИСТОПОРОДНОГО И ПОМЕСНОГО МОЛОДНЯКА СВИ- НЕЙ С РАЗНОЙ ИНТЕНСИВНОСТЬЮ ФОРМИРОВАНИЯ}

\section{А. В. Волощук}

Институт свиноводства и агропромышленного производства НААН (Полтава, Украина)

Приведены результаты исследований по изучению особенностей роста чистопородных и помесных свиней по индексам интенсивности формирования, равномерности и напряженности роста. Изучена зависимость между среднесуточными приростами в возрастные периоды 0-3; 1-3 и 4-6 месяиев с живой массой в 6 месяџев ( $r=0,676^{*} ; 0,667^{*}$ и 0,845**). Статистически значимая корреляция между среднесуточными приростами и индексами роста, определенными в начальный период онтогенеза $(r=0,558-0,950)$, свидетельствует о возможности использования этих показателей при отборе свиней. Полученные результаты свидетельствуют о возможности раннего прогнозирования продуктивности свиней, что будет способствовать увеличению эффективности товарного свиноводства.

Ключевые слова: индексы роста, интенсивность формирования, равномерность, напряженность роста, онтогенез, чистопородный молодняк 
Вступ. На сучасному етапі розвитку свинарства (коли в селекційному процесі використовуюся свині різних генотипів) пріоритетними у наукових дослідженнях є методи удосконалення та прогнозування продуктивних ознак свиней у ранньому онтогенезі. Тому важливого значення набувають питання оцінки формоутворюючих процесів тварин як основи, на якій формується рівень продуктивності у подальші періоди постнатального розвитку залежно від напряму продуктивності [4].

Темпи формування організму тварин на різних стадіях індивідуального розвитку неоднакові, оскільки залежать від спадковості, умов утримання у процесі реалізації генетичної інформації та зумовлені інтенсивністю обміну речовин у процесі життєдіяльності організму. Враховуючи, що жива маса в ранньому віці має позитивну кореляцію з показниками в кінці періоду вирощування або відгодівлі, існує можливість на підставі визначення показників інтенсивності росту виявити їх зв'язок з подальшим ростом свиней та їх продуктивними ознаками.

На даний час дослідження закономірностей онтогенезу ведуться традиційними методами, що передбачають визначення показників живої маси, лінійних промірів та індексів інтенсивності росту $[4,7]$.

Для управління процесами розвитку сільськогосподарських тварин необхідні знання закономірностей морфофункціонального росту та специфічних властивостей організму на кожному етапі індивідуального розвитку $[8,9,10]$. Аналіз наукової літератури доводить, що вивченням питання впливу інтенсивності росту свиней на їх продуктивні ознаки займалося багато вчених $[1,2,3,5,11]$. Однак детальних досліджень закономірностей росту свиней сучасних високопродуктивних генотипів, відселекціонованих на високу інтенсивність росту, за чистопородного розведення та схрещування у свинарстві не проводилося, тому вивчення даного питання залишається наразі актуальним і важливим для розробки критеріїв оцінки і відбору тварин. Доцільно також визначити можливість використання індексів росту для прогнозування живої маси та середньодобових приростів, враховуючи дані, отримані в ранньому онтогенезі.

Мета досліджень - вивчити особливості росту молодняку свиней великої білої породи, поєднань велика біла х ландрас і велика біла х п’єтрен з різною інтенсивністю формування на початковому етапі онтогенезу та встановлення зв'язку індексів росту з продуктивними ознаками у певні періоди онтогенезу.

Матеріал і методика досліджень. Дослідження були проведені в умовах племінного заводу з розведення свиней великої білої породи ДП ДГ «Степне» Полтавського району Полтавської області. Для проведення досліджень було сформовано три групи тварин: I група (контрольна) - ВБ х ВБ (велика біла порода х велика біла порода, $\mathrm{n}=24)$; II група - 1/2 (ВБ х Л) (велика біла порода х ландрас, $\mathrm{n}=26)$ i III група - 1/2 (ВБ х П) (велика біла порода х порода п'єтрен, $\mathrm{n}=26$ ), кожна $з$ яких була поділена на класи за індексом інтенсивності формування [9] у трьохмісячному віці шляхом визначення середніх величин. Для чистопородних тварин великої білої породи середнє значення індексу інтенсивності формування у віковий період 03 міс. становило 0,997 од., для II групи - 1,075 од. і для III групи - 1,052 од. При цьому, до класу плюс-варіант $(\mathrm{M}+)$ відносили особин, що знаходились вище середнього значення у вибірці, а до класу мінус-варіант (М-) - тварин з показником інтенсивності формування нижчим за середній.

Визначення індексів рівномірності та напруги росту визначали за методикою В. П. Коваленка [5].

Статистичну обробку матеріалів досліджень здійснювали за загальноприйнятими методами з використанням програми STATISTICA 12.0. Порівняння середніх арифметичних значень проводили методом Стьюдента, визначення залежностей між ознаками - методом кореляційного аналізу з використанням коефіцієнта кореляції Пірсона. Статистичні гіпотези перевірені на рівнях значущості: ${ }^{*} \mathrm{p}<0,05, * * \mathrm{p}<0,01 \mathrm{i} * * * \mathrm{p}<0,001$. 
Результати досліджень. Жива маса тварин представляє особливий інтерес як у виробничому, так і в науковому аспектах, тому що вона характеризує організм у цілому та пов'язана з багатьма його властивостями. Вікові зміни живої маси показують індивідуальні особливості росту, скороспілості, м'ясності тварин та знаходяться у певному зв'язку з продуктивними якостями, рівнем обмінних процесів та ефективністю використання корму [6].

У результаті проведених досліджень встановлено, що за живою масою при народженні статистично значущої різниці між генотипами свиней встановлено не було. У двомісячному віці поросята великої білої породи збільшили живу масу в 18,9 рази, помісні свині поєднання велика біла х ландрас - у 21,1 рази, велика біла х п’єтрен - у 20,0 разів. Жива маса свиней із двох до чотирьохмісячного віку збільшилась у 1,51-2,13 рази, до того ж тварини великої білої породи збільшили живу масу у 2,13 раза, а помісні свині із 50\% часткою кровності за породами ландрас і п'єтрен, відповідно, у 1,51-2,0 рази. Найбільша жива маса у шість місяців була у тварин поєднання велика біла х ландрас - 106,5 кг, у помісних свиней поєднання 1/2 (ВБ х П) жива маса 3 чотирьох до шестимісячного віку збільшилась у 1,96 рази - це найбільший показник у даний віковий період. Необхідно зазначити, що рівень мінливості ознаки мав загальну тенденцію зменшення 3 віком. Так, якщо при народженні коефіцієнт варіації знаходився в межах від 13,51\% до 23,20\%, то у шестимісячному віці відбулося його скорочення в межах $8,30-13,4 \%$.

При розподілі тварин у межах груп за інтенсивністю формування вищою живою масою відрізнялись плюс-варіантні свині у всіх дослідних групах. При цьому найбільша різниця між контрастними групами була у тварин поєднання $1 \frac{1}{2}$ (ВБ х П), зокрема, у двомісячному віці вона становила $25,49 \%(\mathrm{p} \leq 0,001)$, у трьохмісячному - 16,87\% (p $\leq 0,001)$, у чотирьохмісячному $12,26 \%(\mathrm{p} \leq 0,05)$, у п’ятимісячному віці - $10,3 \%(\mathrm{p} \leq 0,05)$ і у шестимісячному віці - 7,38\%. У свиней поєднання ВБх Л різниця в межах груп за живою масою була невеликою, однак найбільшою вона була у чотирьохмісячному віці - 4,40 кг або 8,26\% $(\mathrm{p} \leq 0,05)$. Чистопородні тварини великої білої породи відрізнялися найменшою різницею в межах групи: мінімальна різниця між контрастними групами за інтенсивністю формування була встановлена у чотирьохмісячному віці - 0,81 кг, а найбільша - у віці чотири місяці і становила 5,12 кг $(\mathrm{p} \leq 0,001)$. Отримані нами дані свідчать, що різниця між різними генотипами свиней була не такою значною, як у межах груп.

Проведений дисперсійний аналіз підтвердив достовірність впливу як на інтенсивність формування, так і на породу, але не встановлено їх взаємодії на показники живої маси у різні вікові періоди.

Про різну швидкість росту свиней різних класів розподілу свідчать їх середньодобові прирости (табл. 1). Приріст маси - це перетворення поживних речовин корму у кісткову, м'язову та жирову тканини. Впродовж початкового періоду онтогенезу, який продовжується до досягнення живої маси 35-40 кг, свині використовують поживні речовини корму для приросту скелету, пропорційного збільшення м'язової тканини та відкладання невеликої кількості жиру. Цей період характеризується тим, що скільки б не потрапляло в організм поживних речовин, надлишок їх використовується, в основному, для росту кісток і м'язів, а незначна їх кількість - на відкладання жиру [2].

Найбільшими середньодобовими приростами у початковому періоді життя (0-1 i 1 4 міс.) відрізнялись тварини поєднання $1 / 2$ (ВБ х Л), які на $14,5 \%(\mathrm{p} \leq 0,05)$ та на 22,8\% ( $\mathrm{p} \leq 0,01)$ перевищували контрольну групу свиней, але у другому віковому періоді (4-6 міс.) значущої різниці між групами встановлено не було. Свині поєднання $1 / 2$ (ВБ х П) поступались аналогам впродовж усього досліду. Але найбільшу зацікавленість представляє порівняльна оцінка середньодобових приростів в межах досліджуваних груп. Так, свині класу мінусваріант першої та третьої дослідних груп відрізнялись високою інтенсивністю росту у віковий період 3 двох до чотирьох місяців. Свині з високою інтенсивністю формування (класу плюс 
варіант) призупинили свій ріст саме в цей період, хоча після чотирьохмісячного віку (з чотирьох до п'яти місяців) мали досить інтенсивний ріст і переважали за середньодобовими приростами тварин класу мінус-варіант на 6,13\% і 2,76\% відповідно.

1. Жива маса та середньодбові прирости в залежності від генотипу та інтенсивності формування

\begin{tabular}{|c|c|c|c|c|c|c|c|c|c|}
\hline \multirow{4}{*}{ Показник } & \multicolumn{9}{|c|}{ Генотипи } \\
\hline & \multicolumn{3}{|c|}{ ВБ $\times$ ВБ $(n=24)$} & \multicolumn{3}{|c|}{$1 / 2($ ВБ $\times$ Л $)(n=26)$} & \multicolumn{3}{|c|}{$1 / 2($ ВБ $\times \Pi)(n=26)$} \\
\hline & \multicolumn{9}{|c|}{ Інтенсивність формування } \\
\hline & $\mathrm{M}+$ & M- & $\begin{array}{l}\text { середнє } \\
\text { по групі }\end{array}$ & $\mathrm{M}+$ & M- & $\begin{array}{l}\text { середнє } \\
\text { по групі }\end{array}$ & $\mathrm{M}+$ & M- & $\begin{array}{l}\text { середнє } \\
\text { по групі }\end{array}$ \\
\hline Вік & \multicolumn{9}{|c|}{ Жива маса, кг } \\
\hline народження & $\begin{array}{l}1,24 \pm \\
0,002\end{array}$ & $\begin{array}{l}1,23 \pm \\
0,002\end{array}$ & $\begin{array}{l}1,24 \pm \\
0,002\end{array}$ & $\begin{array}{l}1,24 \pm \\
0,004\end{array}$ & $\begin{array}{l}1,23 \pm \\
0,003\end{array}$ & $\begin{array}{l}1,24 \pm \\
0,0027\end{array}$ & $\begin{array}{c}1,23 \pm \\
0,009\end{array}$ & $\begin{array}{c}1,24 \pm \\
0,012\end{array}$ & $\begin{array}{l}1,24 \pm \\
0,007\end{array}$ \\
\hline 1 мic. & $\begin{array}{l}8,45 \pm \\
0,207 \\
\end{array}$ & $\begin{array}{l}7,08 \pm \\
0,239 \\
\end{array}$ & $\begin{array}{l}7,71 \pm \\
0,213 \\
\end{array}$ & $\begin{array}{c}9,54 \pm \\
0,310 \\
\end{array}$ & $\begin{array}{c}7,89 \pm \\
0,268 \\
\end{array}$ & $\begin{array}{l}8,65 \pm \\
0,2583\end{array}$ & $\begin{array}{c}9,54 \pm \\
0,514 \\
\end{array}$ & $\begin{array}{l}7,15 \pm \\
0,317 \\
\end{array}$ & $\begin{array}{c}8,35 \pm \\
0,380\end{array}$ \\
\hline 2 мiс. & $\begin{array}{c}25,54 \pm \\
0,947\end{array}$ & $\begin{array}{c}20,38 \pm \\
0,615\end{array}$ & $\begin{array}{c}22,75 \pm \\
0,757\end{array}$ & $\begin{array}{c}27,56 \pm \\
1,069\end{array}$ & $\begin{array}{c}23,28 \pm \\
0,759\end{array}$ & $\begin{array}{c}25,26 \pm \\
0,7596\end{array}$ & $\begin{array}{c}27,46 \pm \\
0,874\end{array}$ & $\begin{array}{c}20,46 \pm \\
0,730\end{array}$ & $\begin{array}{c}23,96 \pm \\
0,895\end{array}$ \\
\hline 3 мiс. & $\begin{array}{c}37,14 \pm \\
0,804\end{array}$ & $\begin{array}{c}34,15 \pm \\
0,781\end{array}$ & $\begin{array}{c}35,52 \pm \\
0,630\end{array}$ & $\begin{array}{c}40,42 \pm \\
1,612\end{array}$ & $\begin{array}{c}36,36 \pm \\
1,249\end{array}$ & $\begin{array}{c}38,23 \pm \\
1,0624\end{array}$ & $\begin{array}{c}39,42 \pm \\
1,272\end{array}$ & $\begin{array}{c}32,77 \pm \\
1,055\end{array}$ & $\begin{array}{c}36,09 \pm \\
1,048\end{array}$ \\
\hline 4 мiс. & $\begin{array}{c}48,73 \pm \\
1,222 \\
\end{array}$ & $\begin{array}{c}47,92 \pm \\
1,052 \\
\end{array}$ & $\begin{array}{c}48,28 \pm \\
0,786 \\
\end{array}$ & $\begin{array}{c}53,25 \pm \\
1,256 \\
\end{array}$ & $\begin{array}{c}48,85 \pm \\
1,603 \\
\end{array}$ & $\begin{array}{c}50,88 \pm \\
1,3948 \\
\end{array}$ & $\begin{array}{c}51,38 \pm \\
1,810 \\
\end{array}$ & $\begin{array}{c}45,08 \pm \\
1,438 \\
\end{array}$ & $\begin{array}{c}48,23 \pm \\
1,296 \\
\end{array}$ \\
\hline 5 міс. & $\begin{array}{c}75,14 \pm \\
1,505\end{array}$ & $\begin{array}{c}72,73 \pm \\
1,640\end{array}$ & $\begin{array}{c}73,73 \pm \\
1,129 \\
\end{array}$ & $\begin{array}{c}80,62 \pm \\
2,652\end{array}$ & $\begin{array}{l}77,0 \pm \\
1,900\end{array}$ & $\begin{array}{c}78,67 \pm \\
1,6031\end{array}$ & $\begin{array}{c}77,27 \pm \\
2,661\end{array}$ & $\begin{array}{c}69,31 \pm \\
1,916\end{array}$ & $\begin{array}{c}73,29 \pm \\
1,796\end{array}$ \\
\hline 6 мiс. & $\begin{array}{c}101,63 \pm \\
2,175\end{array}$ & $\begin{array}{c}97,85 \pm \\
2,488 \\
\end{array}$ & $\begin{array}{c}99,58 \pm \\
1,687 \\
\end{array}$ & $\begin{array}{c}108,0 \pm \\
3,475\end{array}$ & $\begin{array}{c}105,14 \pm \\
2,408 \\
\end{array}$ & $\begin{array}{c}106,46 \pm \\
2,060\end{array}$ & $\begin{array}{c}103,15 \pm \\
4,030\end{array}$ & $\begin{array}{c}95,54 \pm \\
2,786 \\
\end{array}$ & $\begin{array}{c}98,38 \pm \\
2,586 \\
\end{array}$ \\
\hline $\begin{array}{c}\text { Віковий } \\
\text { період }\end{array}$ & \multicolumn{9}{|c|}{ Середньодобовий приріст, кг } \\
\hline 0-1 міс. & $\begin{array}{c}0,240 \pm \\
0,0069 \\
\end{array}$ & $\begin{array}{c}0,195 \pm \\
0,0080 \\
\end{array}$ & $\begin{array}{c}0,215 \pm \\
0,0071 \\
\end{array}$ & $\begin{array}{c}0,277 \pm \\
0,0102 \\
\end{array}$ & $\begin{array}{c}0,222 \pm \\
0,0089 \\
\end{array}$ & $\begin{array}{c}0,247 \pm \\
0,0086 \\
\end{array}$ & $\begin{array}{c}0,277 \pm \\
0,0169 \\
\end{array}$ & $\begin{array}{c}0,197 \pm \\
0,0105 \\
\end{array}$ & $\begin{array}{c}0,237 \pm \\
0,013 \\
\end{array}$ \\
\hline 0-3 міс. & $\begin{array}{c}0,399 \pm \\
0,0089 \\
\end{array}$ & $\begin{array}{c}0,366 \pm \\
0,0087 \\
\end{array}$ & $\begin{array}{c}0,381 \pm \\
0,0070 \\
\end{array}$ & $\begin{array}{c}0,436 \pm \\
0,0179 \\
\end{array}$ & $\begin{array}{c}0,390 \pm \\
0,0139 \\
\end{array}$ & $\begin{array}{c}0,411 \pm \\
0,0118 \\
\end{array}$ & $\begin{array}{c}0,424 \pm \\
0,0141 \\
\end{array}$ & $\begin{array}{c}0,350 \pm \\
0,0117 \\
\end{array}$ & $\begin{array}{c}0,387 \pm \\
0,011 \\
\end{array}$ \\
\hline 1-3 міс. & $\begin{array}{c}0,478 \pm \\
0,0134\end{array}$ & $\begin{array}{c}0,451 \pm \\
0,0117\end{array}$ & $\begin{array}{c}0,463 \pm \\
0,0091\end{array}$ & $\begin{array}{c}0,515 \pm \\
0,0231\end{array}$ & $\begin{array}{c}0,474 \pm \\
0,0176\end{array}$ & $\begin{array}{c}0,493 \pm \\
0,0145\end{array}$ & $\begin{array}{c}0,498 \pm \\
0,0155\end{array}$ & $\begin{array}{c}0,427 \pm \\
0,0135\end{array}$ & $\begin{array}{c}0,463 \pm \\
0,012\end{array}$ \\
\hline 1-4 мiс. & $\begin{array}{c}0,431 \pm \\
0,0127 \\
\end{array}$ & $\begin{array}{c}0,493 \pm \\
0,0101 \\
\end{array}$ & $\begin{array}{c}0,211 \pm \\
0,0087\end{array}$ & $\begin{array}{c}0,581 \pm \\
0,0251 \\
\end{array}$ & $\begin{array}{c}0,532 \pm \\
0,0178 \\
\end{array}$ & $\begin{array}{l}0,554 \pm \\
0,0155\end{array}$ & $\begin{array}{c}0,465 \pm \\
0,0166\end{array}$ & $\begin{array}{c}0,421 \pm \\
0,0133\end{array}$ & $\begin{array}{c}0,443 \pm \\
0,012 \\
\end{array}$ \\
\hline 2-4 мiс. & $\begin{array}{c}0,386 \pm \\
0,0247\end{array}$ & $\begin{array}{c}0,459 \pm \\
0,0122\end{array}$ & $\begin{array}{c}0,425 \pm \\
0,0148\end{array}$ & $\begin{array}{c}0,441 \pm \\
0,0254\end{array}$ & $\begin{array}{c}0,426 \pm \\
0,0181\end{array}$ & $\begin{array}{l}0,433 \pm \\
0,0160\end{array}$ & $\begin{array}{c}0,399 \pm \\
0,0211\end{array}$ & $\begin{array}{c}0,410 \pm \\
0,0144\end{array}$ & $\begin{array}{c}0,404 \pm \\
0,013\end{array}$ \\
\hline 4-6 мiс. & $\begin{array}{c}0,881 \pm \\
0,0288\end{array}$ & $\begin{array}{c}0,832 \pm \\
0,0357\end{array}$ & $\begin{array}{c}0,855 \pm \\
0,0235\end{array}$ & $\begin{array}{c}0,895 \pm \\
0,0424\end{array}$ & $\begin{array}{c}0,938 \pm \\
0,0253\end{array}$ & $\begin{array}{l}0,913 \pm \\
0,0237\end{array}$ & $\begin{array}{c}0,863 \pm \\
0,0545\end{array}$ & $\begin{array}{c}0,808 \pm \\
0,0372\end{array}$ & $\begin{array}{c}0,835 \pm \\
0,033\end{array}$ \\
\hline
\end{tabular}

У помісних тварин поєднання 1/2 (ВБ х Л) спостерігалися інші закономірності росту. Свині класу плюс-варіант з народження до чотирьохмісячного віку відрізнялися високою інтенсивністю росту, але після чотирьох місяців інтенсивність росту почала зменшуватися, а мінус-варіантні свині продовжували інтенсивно рости.

Це підтверджує той факт, що відставання в рості на певному етапі онтогенезу сприяє збільшенню його інтенсивності у наступні вікові періоди, тобто крива росту свиней має хвилеподібний характер, що пов'язано з процесами диференціації, під час яких процес росту уповільнюється.

Нашими дослідженнями були визначені індекси рівномірності, напруги росту та інтенсивності формування в залежності від вікового періоду 0-3 міс., 1-3 міс., 1-4 міс., 2-4 міс. і 4-6 місяців.

Процес формування молодняку у дорослих тварин визначали за індексом інтенсивності формування, який відрізнявся в межах кожної дослідної групи. Динаміка зміни індексу інтенсивності формування у різні вікові періоди показує, що максимальна інтенсивність росту припадає на віковий період від народження до трьох місяців за всіма генотипами, які вивчалися $(\mathrm{I} \phi=1,043 \pm 0,0154)$.

У свиней всіх дослідних груп відмічена однакова закономірність: з двохмісячного віку відбувається зниження інтенсивності росту з підвищенням цього показника у 4 місяці до 0,681 од. та зниженням його до 0,128 - у шість місяців. Варто відмітити, що помісні свині 
1/2 (ВБ х Л) відрізнялися найвищим значенням індексу формування майже у всі вікові періоди, найнижчим цей показник був у тварин великої білої породи. Установлено, що швидкий тип формування, який визначається вищим значенням Іф, пов'язаний з меншим відкладанням жиру в туші порівняно з повільним типом. Отже, можна констатувати, що інтенсивність формування від народження до шести місяців має тенденцію до зниження.

2. Показники інтенсивності росту свиней у різні вікові періоди, $M \pm m$

\begin{tabular}{|c|c|c|c|c|c|}
\hline Генотип & Віковий період, міс. & Клас розподілу & $\mathrm{I} \phi$ & Ip & $\mathrm{IH}$ \\
\hline \multirow{15}{*}{$\begin{array}{l}\text { ВБ } \times \text { ВБ } \\
(n=24)\end{array}$} & \multirow{2}{*}{$0-3$} & + & $1,112 \pm 0,0274$ & $0,842 \pm 0,0229$ & $0,237 \pm 0,0082$ \\
\hline & & - & $0,900 \pm 0,0267$ & $0,697 \pm 0,0234$ & $0,178 \pm 0,0080$ \\
\hline & \multicolumn{2}{|c|}{ Середнє по групі } & $0,997 \pm 0,0288$ & $0,764 \pm 0,0221$ & $0,205 \pm 0,0144$ \\
\hline & \multirow{2}{*}{$1-3$} & + & $0,603 \pm 0,0518$ & $0,296 \pm 0,0098$ & $0,239 \pm 0,0213$ \\
\hline & & - & $0,459 \pm 0,0356$ & $0,310 \pm 0,0069$ & $0,159 \pm 0,0129$ \\
\hline & \multicolumn{2}{|c|}{ Середнє по групі } & $0,525 \pm 0,0334$ & $0,303 \pm 0,0059$ & $0,195 \pm 0,144$ \\
\hline & \multirow{2}{*}{$1-4$} & + & $0,707 \pm 0,0415$ & $0,260 \pm 0,0102$ & $0,231 \pm 0,0127$ \\
\hline & & - & $0,631 \pm 0,0299$ & $0,279 \pm 0,0065$ & $0,193 \pm 0,0100$ \\
\hline & \multicolumn{2}{|c|}{ Середнє по групі } & $0,666 \pm 0,0256$ & $0,270 \pm 0,0061$ & $0,271 \pm 0,0087$ \\
\hline & \multirow{2}{*}{$2-4$} & + & $0,104 \pm 0,0114$ & $0,429 \pm 0,0313$ & $0,064 \pm 0,0074$ \\
\hline & & - & $0,171 \pm 0,0083$ & $0,538 \pm 0,0163$ & $0,097 \pm 0,0042$ \\
\hline & \multicolumn{2}{|c|}{ Середнє по групі } & $0,140 \pm 0,0097$ & $0,488 \pm 0,0199$ & $0,082 \pm 0,0052$ \\
\hline & \multirow{2}{*}{$4-6$} & + & $0,128 \pm 0,0081$ & $0,996 \pm 0,0360$ & $0,160 \pm 0,0095$ \\
\hline & & - & $0,117 \pm 0,0078$ & $0,932 \pm 0,0444$ & $0,144 \pm 0,044$ \\
\hline & \multicolumn{2}{|c|}{ Середнє по групі } & $0,122 \pm 0,0056$ & $0,961 \pm 0,0293$ & $0,151 \pm 0,0075$ \\
\hline \multirow{15}{*}{$\begin{array}{c}1 / 2(\text { ВБ } x ~ Л) \\
(n=26)\end{array}$} & \multirow{2}{*}{$0-3$} & + & $1,157 \pm 0,0158$ & $0,940 \pm 0,0418$ & $0,264 \pm 0,0121$ \\
\hline & & - & $1,005 \pm 0,0165$ & $0,784 \pm 0,0090$ & $0,205 \pm 0,0090$ \\
\hline & \multicolumn{2}{|c|}{ Середнє по групі } & $1,075 \pm 0,0189$ & $0,856 \pm 0,0296$ & $0,232 \pm 0,0093$ \\
\hline & \multirow{2}{*}{$1-3$} & + & $0,591 \pm 0,0339$ & $0,324 \pm 0,0453$ & $0,247 \pm 0,0166$ \\
\hline & & - & $0,548 \pm 0,0283$ & $0,307 \pm 0,0117$ & $0,202 \pm 0,0117$ \\
\hline & \multicolumn{2}{|c|}{ Середнє по групі } & $0,568 \pm 0,0218$ & $0,315 \pm 0,0092$ & $0,223 \pm 0,0107$ \\
\hline & \multirow{2}{*}{$1-4$} & + & $0,695 \pm 0,0290$ & $0,875 \pm 0,0454$ & $0,290 \pm 0,0158$ \\
\hline & & - & $0,692 \pm 0,0265$ & $0,805 \pm 0,0121$ & $0,255 \pm 0,0121$ \\
\hline & \multicolumn{2}{|c|}{ Середнє по групі } & $0,693 \pm 0,0192$ & $0,837 \pm 0,0289$ & $0,271 \pm 0,0102$ \\
\hline & \multirow{2}{*}{$2-4$} & + & $0,110 \pm 0,0103$ & $0,492 \pm 0,0315$ & $0,075 \pm 0,0071$ \\
\hline & & - & $0,144 \pm 0,0141$ & $0,488 \pm 0,0102$ & $0,087 \pm 0,0102$ \\
\hline & \multicolumn{2}{|c|}{ Середнє по групі } & $0,128 \pm 0,0094$ & $0,489 \pm 0,0186$ & $0,082 \pm 0,0064$ \\
\hline & \multirow{2}{*}{$4-6$} & + & $0,109 \pm 0,0132$ & $0,997 \pm 0,0564$ & $0,147 \pm 0,0174$ \\
\hline & & - & $0,140 \pm 0,0066$ & $1,071 \pm 0,0078$ & $0,179 \pm 0,0078$ \\
\hline & \multicolumn{2}{|c|}{ Середнє по групі } & $0,126 \pm 0,0076$ & $1,037 \pm 0,0311$ & $0,164 \pm 0,0094$ \\
\hline \multirow{15}{*}{$\begin{array}{c}1 / 2(\text { ВБ } \times \text { П }) \\
(\mathrm{n}=26)\end{array}$} & & + & $1,173 \pm 0,0245$ & $0,924 \pm 0,0366$ & $0,244 \pm 0,0156$ \\
\hline & $0-3$ & - & $0,931 \pm 0,0269$ & $0,679 \pm 0,0297$ & $0,221 \pm 0,0097$ \\
\hline & Середнє п & групі & $1,052 \pm 0,0300$ & $0,802 \pm 0,0336$ & $0,232 \pm 0,0093$ \\
\hline & $1-3$ & + & $0,618 \pm 0,0321$ & $0,852 \pm 0,0282$ & $0,249 \pm 0,0111$ \\
\hline & $1-3$ & - & $0,502 \pm 0,0258$ & $0,704 \pm 0,0250$ & $0,167 \pm 0,0097$ \\
\hline & Середнє п & групі & $0,560 \pm 0,0233$ & $0,778 \pm 0,0236$ & $0,208 \pm 0,0110$ \\
\hline & & + & $0,713 \pm 0,0285$ & $0,794 \pm 0,0273$ & $0,239 \pm 0,0085$ \\
\hline & $1-4$ & - & $0,650 \pm 0,0224$ & $0,695 \pm 0,0233$ & $0,188 \pm 0,0078$ \\
\hline & Середнє п & групі & $0,681 \pm 0,0189$ & $0,745 \pm 0,0202$ & $0,213 \pm 0,0076$ \\
\hline & $2-4$ & + & $0,095 \pm 0,0066$ & $0,438 \pm 0,0252$ & $0,063 \pm 0,0052$ \\
\hline & $2-4$ & - & $0,147 \pm 0,0062$ & $0,471 \pm 0,0176$ & $0,080 \pm 0,0038$ \\
\hline & Середнє п & групі & $0,121 \pm 0,0069$ & $0,455 \pm 0,0154$ & $0,072 \pm 0,0036$ \\
\hline & 1 & + & $0,117 \pm 0,0105$ & $0,970 \pm 0,0686$ & $0,153 \pm 0,0156$ \\
\hline & $4-6$ & - & $0,157 \pm 0,0295$ & $0,934 \pm 0,0475$ & $0,177 \pm 0,0291$ \\
\hline & Середнє п & групі & $0,137 \pm 0,0159$ & $0,952 \pm 0,0410$ & $0,165 \pm 0,0163$ \\
\hline
\end{tabular}
росту. 
Проведеними дослідженнями встановлено, що найвища інтенсивність формування характерна для плюс-варіантних тварин всіх генотипів на початковому етапі онтогенезу, проте у віковий період 2-4 місяці свині класу мінус-варіант переважали однолітків плюс-варіант I групи на 0,067 од. $(\mathrm{p} \leq 0,05)$, II - на 0,034 од. i III - на 0,034 од. $(\mathrm{p} \leq 0,001)$.

Однак, у віковий період 4-6 місяців інтенсивність формування чистопородних тварин великої білої породи класу плюс-варіант збільшилась на 0,024 од. і мала тенденцію до переваги над аналогами мінус-варіант на 0,011 од. Разом з тим помісні тварини класу мінус-варіант II та III дослідних груп мали тенденцію до збільшення індексу інтенсивності формування на 0,31-0,40 од. порівняно з аналогами, тобто їх швидкість росту у цей період залишалася високою.

Показник напруги росту у свиней контрольної групи був найвищим від народження до трьохмісячного віку (0,237-0,239 од.) з поступовим його зниженням до чотирьохмісячного віку та невеликим збільшенням до шести місяців. Відомо, що напруга росту у будь-який період онтогенезу залежить від середньодобового приросту. На початковому етапі онтогенезу (у віковий період 0-3 місяці) напруга росту у свиней поєднання $1 \frac{2}{2}$ (ВБ х Л) була найвищою, а 3 трьох до чотирьохмісячного віку вона ще збільшилась на 21,5\% і за значенням індексу напруги перевищувала однолітків контрольної групи на $22,1 \%(\mathrm{p} \leq 0,001)$ та свиней III дослідної групи на $21,4 \%$ ( $\leq 0,001)$. Характерною особливістю росту поєднання $1 / 2$ (ВБ х Л) є висока напруга росту у мінус-варіантних тварин в усі досліджувані періоди порівняно з однолітками класу плюс-варіант, але особливо у період 4-6 місяців, коли статистично значуща різниця значення індексу напруги росту між контрастними групами становило 0,924 од. (p < 0,001).

Отримані нами дані свідчать про більшу тривалість активного росту саме у свиней класу мінус-варіант поєднання ВБ х Л.

У молодняку свиней III дослідної групи класу плюс-варіант відмічалася підвищена напруга росту від народження до трьох місяців $(0,244-0,249$ од.) з поступовим іiї зниженням у чотири місяці (0,063 од.) та невеликим збільшенням у п’ятимісячному віці $(0,153$ од.). Проте у мінус-варіантних свиней цього поєднання збільшення напруги росту відбулося у віковий період 4-6 місяців і вони мали тенденцію до переваги над аналогами на 0,024 од.

Щодо показника рівномірності росту, то необхідно відмітити, що найбільше значення цього показника припадає на періоди 0-3 та 4-6 місяців у всіх досліджуваних тварин.

3 метою вивчення критеріїв відбору ремонтного молодняку були визначені коефіцієнти кореляції між індексами інтенсивності росту та рівнем середньодобових приростів і живої маси (табл. 3). Встановлено, що індекс інтенсивності формування мав високу позитивну кореляцію із середньодобовими приростами у віковий період 0-3 та 2-4 місяці (відповідно $\mathrm{r}=0,650-0,558)$, у ці періоди спостерігався досить високий зв'язок між приростами та напругою росту $(\mathrm{r}=0,560-0,748)$, хоча найвище значення коефіцієнта кореляції було відмічено у віковий період 1-4 місяці - 0,950. Найбільш інформативним виявився індекс рівномірності росту $(\mathrm{r}=0,638-0,986)$.

3. Коефіцієнти кореляції індексів росту та живої маси свиней з ̈̈х середньодобовими приростами

\begin{tabular}{|c|c|c|c|c|c|c|c|c|c|}
\hline \multirow{2}{*}{$\begin{array}{c}\text { С/д приріст у } \\
\text { віковий період, } \\
\text { міс. }\end{array}$} & \multicolumn{6}{|c|}{ Жива маса, кг } & \multicolumn{3}{|c|}{ Індекси росту } \\
\hline & 1 мic. & 2 мic. & 3 мiс. & 4 мic. & 5 мic. & 6 мiс. & Iф & Ip & $\mathrm{IH}$ \\
\hline $0-3$ & $\begin{array}{c}0,786 \pm \\
0,0244\end{array}$ & $\begin{array}{c}0,552 \pm \\
0,0514\end{array}$ & $\begin{array}{c}0,414 \pm \\
0,0672\end{array}$ & $\begin{array}{c}0,534 \pm \\
0,0534\end{array}$ & $\begin{array}{c}0,837 \pm \\
0,0187\end{array}$ & $\begin{array}{c}0,676 \pm \\
0,0187\end{array}$ & $\begin{array}{c}0,650 \pm \\
0,0401\end{array}$ & $\begin{array}{c}0,649 \pm \\
0,0402\end{array}$ & $\begin{array}{c}0,560 \pm^{*} \\
0,0504\end{array}$ \\
\hline $1-3$ & $\begin{array}{c}0,608 \pm \\
0,0449\end{array}$ & $\begin{array}{c}0,531 \pm \\
0,0538\end{array}$ & $\begin{array}{c}0,392 \pm \\
0,0697\end{array}$ & $\begin{array}{c}0,530 \pm \\
0,0539\end{array}$ & $\begin{array}{c}0,827 \pm \\
0,0198\end{array}$ & $\begin{array}{c}0,667 \pm \\
0,0198\end{array}$ & $\begin{array}{c}0,278 \pm \\
0,0828\end{array}$ & $\begin{array}{c}0,673 \pm \\
0,0375\end{array}$ & $\begin{array}{c}0,125 \pm \\
0,1003\end{array}$ \\
\hline $1-4$ & $\begin{array}{c}0,458 \pm \\
0,0621\end{array}$ & $\begin{array}{c}0,790 \pm \\
0,0241\end{array}$ & $\begin{array}{c}-0,299 \pm \\
0,1489\end{array}$ & $\begin{array}{c}-0,206 \pm \\
0,1383\end{array}$ & $\begin{array}{c}0,483 \pm \\
0,0593\end{array}$ & $\begin{array}{c}0,417 \pm \\
0,0668\end{array}$ & $\begin{array}{c}0,183 \pm \\
0,0937\end{array}$ & $\begin{array}{c}0,638 \pm \\
0,0415\end{array}$ & $\begin{array}{c}0,950 \pm \\
0,0057\end{array}$ \\
\hline $2-4$ & $\begin{array}{c}0,248 \pm \\
0,0862 \\
\end{array}$ & $\begin{array}{c}0,223 \pm \\
0,0891\end{array}$ & $\begin{array}{c}0,118 \pm \\
0,1011 \\
\end{array}$ & $\begin{array}{c}0,389 \pm \\
0,0701 \\
\end{array}$ & $\begin{array}{c}0,588 \pm \\
0,0472\end{array}$ & $\begin{array}{c}0,463 \pm \\
0,0472\end{array}$ & $\begin{array}{c}0,558 \pm \\
0,0207\end{array}$ & $\begin{array}{c}0,986 \pm \\
0,0016\end{array}$ & $\begin{array}{c}0,748 \pm \\
0,0289\end{array}$ \\
\hline $4-6$ & $\begin{array}{c}0,155 \pm \\
0,0969\end{array}$ & $\begin{array}{c}0,284 \pm \\
0,0821\end{array}$ & $\begin{array}{c}-0,078 \pm \\
0,1236\end{array}$ & $\begin{array}{c}-0,029 \pm \\
0,1180\end{array}$ & $\begin{array}{c}0,667 \pm \\
0,0382\end{array}$ & $\begin{array}{c}0,845 \pm \\
0,0382\end{array}$ & $\begin{array}{c}0,292 \pm \\
0,0812\end{array}$ & $\begin{array}{c}0,976 \pm \\
0,0027\end{array}$ & $\begin{array}{c}0,544 \pm \\
0,0523\end{array}$ \\
\hline
\end{tabular}


Висновки. 1. Встановлено, що відмінності у параметрах росту свиней великої білої породи та помісей поєднань $1 / 2$ (ВБ х Л) i 1/2 (ВБ х П) $(3,0-12,3 \%, p \leq 0,001)$ обумовлені швидким спадом інтенсивності росту свиней великої білої породи $(\mathrm{I \phi}=0,122)$ порівняно $з$ іншими генотипами (Iф = 0,137).

2. Виявлені високі залежності між середньодобовими приростами у вікові періоди 0-3; $1-3$ і 4-6 місяців з живою масою у 6 місяців $(\mathrm{r}=0,676 ; 0,667$ і 0,845).

3. Статистично значуща кореляція між середньодобовими приростами та індексами росту, визначеними в початковий період онтогенезу $(\mathrm{r}=0,558-0,950)$, свідчить про доцільність використання цих показників при відборі свиней.

\section{БІБЛІОГРАФІЯ}

1. Акнєвський, Ю. П. Закономірності росту свиней різних генотипів / Ю. П. Акнєвський, Л. П. Гришина // Вісник аграрної науки Причорномор'я. - Миколаїв, 2006. - Вип. 3 (35), т. 2. C. 166-169.

2. Балабанова, І. О. Моделювання кривих росту свиней з різною інтенсивністю формування в ранньому онтогенезі / I. О. Балабанова // Вісник аграрної науки Причорномор'я. - Миколаїв, 1999. - Вип. 2. - С. 127-129.

3. Гришина, Л. П. Влияние интенсивности роста на откормочные и мясные качества свиней разных генотипов /Л. П. Гришина, Ю. П. Акневский // Свинарство. - 2007. - № 55. - С. $20-28$.

4. Гришина, Л. П. Прогнозування продуктивності свиней за індексами росту в ранньому онтогенезі / Л. П. Гришина // Свинарство. - 2012. - № 60. - С. 50-55.

5. Коваленко, В. П. Сучасні методи оцінки і прогнозування закономірностей онтогенезу тварин і птиці / В. П. Коваленко, Т. І. Нежлукченко, С. Я. Плоткін // Вісник аграрної науки. 2008. - № 2. - С. 40-45.

6. Колесник, Н. Н. Генетика живой массы скота / Н. Н. Колесник. - К. : Урожай. - 1985. $184 \mathrm{c}$.

7. Рекомендации по использованию основных селекционируемых признаков сельскохозяйственных животных и птицы / В. П. Коваленко, С. Ю. Болелая, Ю. П. Полупан, С. Я. Плоткин. - Херсон, 1997. - 44 с.

8. Свечин, К. Б. Индивидуальное развитие животных / К. Б. Свечин. - К. : Урожай. - 1976. $287 \mathrm{c}$.

9. Свечин, Ю. К. Интенсивность формирования и конституция свиней / Ю. К. Свечин // Вестник с.-х. науки. - 1974.- № 10. - С. 69-76.

10. Свечин, Ю. К. Прогнозирование продуктивности животных в раннем онтогенезе / Ю. К. Свечин // Вестник сельскохозяйственной науки. - 1985. - № 4. - С. 103-108.

11. Топчій, Л. І. Індексна оцінка росту і розвитку свиней асканійського типу української м’ясної породи / Л. І. Топчій // Вісник аграрної науки. - 2007. - № 9. - С. 75-76.

\section{REFERENCES}

1. Aknjevs'kyj, Ju. P., and L. P. Gryshyna. 2006. Zakonomirnosti rostu svynej riznyh genotypiv Growth of pigs of common genotypes. Visnyk agrarnoi' nauky Prychornomor'ja - Bulletin of the Agrarian Science of the Black Sea Region. 3(35):166-169 (in Ukrainian).

2. Balabanova, I. O. 1999. Modeljuvannja kryvyh rostu svyne z riznoju intensyvnistju formuvannja v rann'omu ontogenezi - Modeling of growth curves of pig with different intensity of formation in early ontogenesis. Visnyk agrarnoi nauky Prychornomor'ja - Bulletin of the Agrarian Science of the Black Sea Region. 2:127-129 (in Ukrainian).

3. Hryshyna, L. P., and Yu. P. Aknevskyy. 2008. Intensivnost' rosta, otkormochnye i myasnye kachestva svinej raznyh genotipov - The intensity grows, fattening and meat quality of pigs of different genotypes. Svynovodstvo - Pig breeding. 2:3-6 (in Russian).

4. Gryshyna, L. P. 2012. Prognozuvannja produktyvnosti svynej za indeksamy rostu v rann'omu ontogenezi - Prediction performance of pigs on growth indices in early ontogeny. Svynarstvo - Pig breeding. 60:50-55 (in Ukrainian). 
5. Kovalenko, V. P., T. I. Nezhlukchenko, and S. Y. Plotkin. 2008. Suchasni metody otsinky i prohnozuvannya zakonomirnostey ontohenezu tvaryn i ptytsi - Modern methods of assessment and prediction of ontogenesis patterns of animals and birds. Visnyk ahrarnoi nauky - Bulletin of Agrarian Science. 2:40-45 (in Ukrainian).

6. Kolesnyk, N. N. 1985. Genetyka zhyvoj massy skota - Genetics of live weight of cattle. Kyiv, Urozhaj,184 (in Russian).

7. Kovalenko, V. P., S. Yu. Bolelaya, Yu. P. Polupan, and S. Ya. Plotkyn. 1997. Rekomendacii po ispol'zovaniyu osnovnyh selekcioniruemyh priznakov s.-h. zhivotnyh i pticy - The recommendations for using the major selectable features of agricultural animals and poultry. Kherson, 44 (in Russian).

8. Svechyn, K. B. 1976. Individual'noe razvitie zhivotnyh - Individual development of animals. Kyiv, Urozhaj, 287 (in Russian).

9. Cvechyn, Ju. K. 1974. Intensivnost' formyrovanyja y konstytucyja svynej - Intensity of formation and constitution of pigs. Vestnyk sel'skokhozyaystvennoy nauky - Bulletin of Agricultural Science. 10:69-76 (in Russian).

10. Svechyn, Yu. K. 1985. Prognozirovanie produktivnosti zhivotnyh v rannem ontogeneze - The forecasting of animal productivity in the early ontogenesis. Vestnyk sel'skokhozyaystvennoy nauky Bulletin of Agricultural Science. 4:103-108 (in Russian).

11. Topchiy, L. I. 2007. Indeksna otsinka rostu i rozvytku svyney askaniys'koho typu ukrayins'koyi m"yasnoyi porody - An indexed assessment of the growth and development of the Askanian type of Ukrainian meat breed. Visnyk ahrarnoi nauky - Bulletin of Agrarian Science. 9:7576 (in Ukrainian).

УДК 636.92.033.082.2

\section{РІВЕНЬ ПРОДУКТИВНОСТІ КРОЛІВ РІЗНИХ ПОРІД ТА ЕФЕКТИВНІСТЬ ВИКОРИСТАННЯ СЕЛЕКЦІЙНИХ ІНДЕКСІВ В КРОЛІВНИЦТВІ}

\section{О. М. ГАВРИШ \\ Черкаська дослідна станція біоресурсів НААН (Черкаси, Україна) bioresurs.ck@ukr.net}

Досліджено рівень продуктивності кролів різних порід в умовах промислової технологіі розведення на базі кролеферм СГ ПП «Марчук Н.В.» та дослідній кролефермі Черкаської дослідної станиії біоресурсів НААН (Черкаська обл.). Встановлено, щуо за показниками живої маси перевагу над аналогами мали кролі новозеландської білої породи. Індекс збитості свідчить про вищу м'ясну продуктивність кролів порід м'ясного напряму селекції новозеландська біла та каліфорнійська, коефіцієнти по групах яких становила 62-66\%, щуо на 6 та 10\% вище аналогічного показника по досліджуваній групі кролів породи полтавське срібло $(P>0,999)$. Показник плідності кролематок піддавався мінливості як всередині досліджуваних популяиій так і поколінь, загалом варіював в межах 8,10-8,30 голів. Використання індексної оцінки тварин та аналіз різних схем їх схрещування, дає змогу стверджувати, щзо максимальні показники живої маси мали нащадки тварин, селекційні індекси яких для самщів становили не нижче 60 балів, самок - 55 балів відповідно, щуо слід враховувати при плануванні селекційної роботи 3 популяціями.

Ключові слова: кролі, жива маса, статі тіла, м'ясна продуктивність відтворювальна здатність, селекційні індекси 